\title{
Phytochemical Analysis and Efficacy Of Rosemary (Rosmarinus Officinalis) and Mint (Mentha Spicata) Extracts Against Fall Armyworm (Spodoptera Frugiperda) on Baby Corn (Zea Mays)
}

\author{
Redempta S. Kalinda., Naomi B. Rioba* \\ School of Agriculture and Biotechnology, University of Kabianga, P.O. Box 2030-20200, Kericho, Kenya \\ *Corresponding author email: naomirioba@kabianga.ac.ke
}

\section{DOI: 10.2478/acmy-2020-0011}

\begin{abstract}
:
Fall armyworm (Spodoptera frugiperda, J.E. Smith) is a pest with devasting effects on maize. A laboratory biassay was conducted to analyse the phytochemicals and determine the efficacy of M. spicata and R. officinalis extracts on FAW. Treatments were laid out in a Completely Randomized Design (CRD) with 3 replications. The factors included solvent [Methanol (Me), dichloromethane (DCM), distilled water (Di)] and the plant species (M. spicata and R. officinalis). Coragen SC 200 (Co) and Distilled water (Di) were the positive and negative controls, respectively. FAW rearing, plant extract preparation and phytochemical screening were done using standard procedure. Data collection and analysis was done using standard procedures. The extract yield was highest for R. officinalis regardless of the solvent used. Me-R. officinalis and Di-M. spicata extracts yielded the highest. Saponins, glycosides, alkaloid, flavonoids and tannins. Flavonoid contents were $7.9036 \mathrm{mg} / \mathrm{mL}$ and $6.0073 \pm 0.6117 \mathrm{mg} / \mathrm{mL}$ in methanolic extract of M. spicata and R. officinalis, respectively. M. spicatha and R. officinalis extracts caused 100\% mortality to 3rd instar larvae. Based on the findings, both M. spicata and R. officinalis have several secondary metabolites that confer insecticidal activity of the plants against FAW, hence should be evaluated under field conditions.
\end{abstract}

Keywords: Variety SG 18, Fall Armyworm, lamiaceae, botanicals.

\subsection{Introduction}

Baby corn (Zea may L.) a graminae refers to young corn ears [1] harvested right after silk emergence and consumed fresh or as preserves. It is considered the safest vegetable that is rich in proteins, carbohydrates, iron, phosphorus, $\beta$-carotenes and ascorbic acid [2]. In Kenya, baby corn is mainly produced for export by both small scale and large scale farmers. In 2014, it was grown on 567 Ha producing 4784 MT which had a value of KES 110 millions [3]. It has been shown that for successful baby corn production relies on among others, good cultural management which includes pest and disease control [4]. Like grain maize, it is attacked by many pests like beet armyworm (Spodoptera exigue) [5], corn stem borer (Ostrinia furnacallis)[6] and now the recently introduced and most problematic Fall armyworm (Spodoptera frugiperda) (FAW) [7].

A native to the Americas, the FAW was first reported in Kenya in March, 2016 [7]. It plays host to 186 species from 42 families [8]. This pest causes a big food security threat to Kenya because it is a pest of staple crops like maize, sorghum and millet as emphasized by [9]. There are efforts by stakeholders to manage this pest using various methods; chemical pesticides, cultural methods, biological control and use of botanicals. None of these methods will be effective against FAW since each one of them has been shown to have deficiencies. [9] reported that the preference should be given to a sustainable, costeffective method that causes minimal risk to humans and the environment by using a combination of control methods in an integrated pest management (IPM) strategy. However, because of the magnitude of the damage by FAW, most farmers have found chemical control their best method for managing this pest. This has been not sustainable because most farmers have limited access to pesticides hence the need to search for cheap, accessible and sustainable alternatives such as the use of extracts based on locally available plants like Mint (Mentha spicata and Rosemary (Rosemarinus officinalis).

Mint essential oil has been used against various insect pests; peach-potato aphid (Myzus persicae) [10]; mosquitoes [11- 12]; black bean aphid (Aphis fabae) larvae [13]. Similarly some studies were conducted on rosemary essential oils for pest management; spidermite (Tetranychus urticae)[14-15], pests of stored products [16-17], onion thrips (Thrips tabaci) [18], Pseudaletia unipuncta, cabbage looper (Trichoplusia ni [19], Trogoderma granarium and Tribolium castaneum [20]; Oryzaephilus surinamensis and T. castaneum [21]. There is a clear indication that there is limited literature on the use of leaf extracts of these plants for the management of crop pests and specifically FAW. This study therefore sought to evaluate the efficacy of M spicata and R officinalis for the management of FAW under laboratory conditions.

\subsection{Materials and Methods}

\subsection{Experimental Site Description}

\subsubsection{Baby corn.}

The plant material used was Baby corn; variety SG 18. It was planted in plastic pots ( $25 \mathrm{~cm}$ height $\mathrm{x} 30 \mathrm{~cm}$ width and $50 \mathrm{~cm}$ length) in a greenhouse at the University of Kabianga, School of Agriculture and Biotechnology Farm. The plants were watered as required. Four weeks after seedling emergence, the plants were used as a source of treated leaves for the bioassay.

\subsubsection{Rosmarinus officinalis and Mentha spicata}

Leaves of R. officinalis and M. spicata were collected from farms in Nakuru, Kenya. The plants were identified as such by a taxonomist. The collected materials were washed, shade dried under room temperature and powdered using an electric blender. Five hundred grams $(500 \mathrm{~g})$ were macerated with 1.5 litres of dichloromethane, methanol and distilled water sequentially for a period of 72 hours each and then filtered by Whatman No. a filter paper. The extracts were concentrated at reduced temperature on a rotary evaporator and stored until use. The same procedure was successively repeated for the other solvents (methanol and distilled water). The yield of each was determined under each solvent used for extraction.

\subsection{Fall Armyworm}

Fall Armyworm starter colony was obtained from unsprayed maize farm in Litein and identified as such by an entomologist. About 100 fourth instar larvae were collected and placed in plastic containers and placed in the laboratory and fed them with maize leaves collected from 15-30 days maize plants. The pupae were collected and placed in a moistened Petri-dish in a net cage. Sterile cotton soaked in a sugar solution was placed in a petri-dish inside the net cage as a food source for the emerging adults. The walls of the net cage were lined with wax paper as an oviposition media [22-24]. Eggs were monitored daily for hatching; as soon as the first instars emerged, they were provided with tender and fresh baby corn leaves [22]. The insects were reared as described above until sufficient population was maintained to run the experiment. The rearing was done at room temperature 24-26 0C and 40-50 \% RH. Second generation (F2) larvae was used for the study.

\subsection{Experimental Design and Treatments}

Treatments were laid out in a Completely Randomized Design (CRD) with 3 replications. The factors included solvent used in extraction and the type of plant used. The solvent of extraction factor consisted of Methanol extract (Me), dichloromethane extract (DCM), distilled water extract (Di), positive control (Co) and Negative control (Di). The plant type factor consisted of R. officinalis (R) and M. spicata (M). Maize shoots were obtained from the 4 weeks old seedlings grown in the farm as described above. The shoots were cut $2-3 \mathrm{~cm}$ length and weighed to $3 \mathrm{~g}$. The pieces were placed in a petri-dish and sprayed 
with $3 \mathrm{ml}$ of each of the prepared botanical extracts and the controls. Five third-instar larvae were released into the petri-dish containing the treated leaves five minutes after leaves were treated. Leaves treated with Coragen 200 SC constituted the positive control and those treated with distilled water constituted the negative control.

\subsection{Data Collection}

Data was collected on the following parameters.

\subsubsection{Determination of the extraction yield}

The extraction yield (\%) was calculated as follows:

Extraction yield (\%) =Weight of the extract after evaporating the solvent $\mathrm{x}$ 100/Dry weight of the sample

\subsubsection{Charaterization of phytochemical composition of $M$. spicata and $R$. officinalis}

$1 \mathrm{~g}$ and $0.5 \mathrm{~g}$ of crude extract was measured for both M. spicata and R. officinalis respectively and constituted in $10 \mathrm{ml}$ of DCM, $10 \mathrm{ml} \mathrm{methanol} \mathrm{and} 10 \mathrm{ml}$ distilled water in its respective concentration. $1 \mathrm{ml}$ of the M. spicata - and R. officinalis -dichloromethane, methanol and distilled filtrate was added to vails. The vails were labelled with the phytochemicals under analysis as saponins, flavonoids, glycosides, alkaloids and tannins respectively for each organic solvent used. The respective phytochemicals were tested as per the standard procedures with slight modifications as described by [25-27] as indicated here below:

a. Saponins: Adding $2 \mathrm{ml}$ of distilled water in the extract then shaking gently; soapy characteristics indicated the presence of saponins.

b. Flavonoids: Into $1 \mathrm{ml}$ of the sample, $2 \mathrm{ml}$ of ammonium hydroxide solution was added. Two to three drops of concentrated sulphuric acid was then added presence of yellow coloration indicated the presence of flavonoids.

c. Glycosides: $\mathrm{In} 1 \mathrm{ml}$ of the plant extract addition of $2 \mathrm{ml}$ of acetic acid followed by $5 \%$ ferric chloride, and 2-3 drops of concentrated sulphuric acid were made; a reddish brown ring indicated the presence of glycosides.

d. Alkaloids: In $1 \mathrm{ml}$ of the plant extract, $1 \mathrm{ml}$ of Wagner's reagent (i.e. potassium iodide iodine) and 3 drops of concentrated sulphuric acid were added; deep brown appearance indicated presence of alkaloids.

e. Tannins: To $1 \mathrm{ml}$ of the plant extract, $2 \mathrm{ml}$ of ferric chloride was added; distinct layer indicates presence of tannins.

\subsubsection{Quantification of Flavonoids in M spicata and Me-R officinalis-Methanol}

The total flavonoid content of M spicata and R officinalis-Methanolic extracts was estimated by the method described by [28] with some modifications. 1.0 $\mathrm{mL}$ of the extracts was mixed with $4.0 \mathrm{~mL}$ of distilled water and subsequently with $0.30 \mathrm{~mL}$ of $10 \%$ NaNo2 solution. After $5 \mathrm{minu}$ tes, $0.30 \mathrm{~mL}$ of $10 \%$ AlCl3 solution followed by $2.0 \mathrm{~mL}$ of $1 \% \mathrm{NaOH}$ solution were added to the mixture. Immediately, the mixture was thoroughly mixed and absorbance determined at $510 \mathrm{~nm}$ versus the blank. A standard curve of catechin was prepared $(0-1.25 \mathrm{~mL} / \mathrm{mL})$ and the flavonoid concentrartion expressed as catechin equivalents (mg catechin/g dried sample)

\subsubsection{Larvae mortality}

Larvae mortality was assessed after 24 hours and 48 hours (when all the larvae had died) after treatment application. A larvae was considered dead if it could not move itself when placed on its dorsal surface. Data on the presence of live larvae petri-dish indicated that a treatment was not effective (as given by a negative sign) while presence of dead FAW larvae on the petri-dish indicated effectiveness of the treatment against the FAW (as given by a positive sign).

\subsection{Data Analysis}

Data on extraction yield, phytochemical screening and larvae mortality were qualitatively analysed and the results presented in form of tables.

\subsection{Results and Discussion}

\subsection{Extract Yield}

Different solvents yielded different amounts of extracts. $\mathrm{R}$ officinalis had the highest extraction yield across the solvents used. However, methanol yielded the highest (13.18\%) extract with R officinalis while distilled water gave the highest (5.76\%) mint extract. DCM yield the least (0.86\%) and (2.04\%) for M spicata and R officinalis, respectively (Table 1).

Table 1: Effects of solvents on extraction yield of M spicatha and R officinalis

\begin{tabular}{|l|l|l|l|}
\hline & Extraction \% yield (w/w) & METHANOL & DISTILLED WATER \\
\hline Plant & DCM & 1.07 & 5.76 \\
\hline M spicatha & 0.86 & 13.18 & 7.43 \\
\hline R officinalis & 2.04 & & \\
\hline
\end{tabular}

\subsection{Charaterization of phytochemical composition of M. spicata and R. officinalis}

Plants synthesize a wide array of secondary metabolism compounds that are generally thought to be involved in plant-insect interactions. Water extracts of Mentha piperita have been shown to have alkaloids, saponins, glycosides, tannins and flavonoids [29]. On the other hand, several phytocompounds have been isolated from essential oils and extracts of R. officinalis [30]. The current study also reports the presence of saponins in R. officinalis only, alkaloids, glycosides, tannins and flavonoids in both plant species. There were slight variations in availability based on the solvent used for extraction.

\subsubsection{Saponins}

Saponins are widely distributed plant glycosides divided into triterpenoid and steroidal saponins that contribute to plant defense mechanisms against herbivores [31]. Studies have shown the presence of saponins in methanolic extract of R officinalis leaves [32]. However, there are contradicting reports on the presence of saponins in mint. The current study revealed that saponins were absent in M. spicata regardless of the solvent used as was reported by [33] for Mentha longifolia methanolic extracts. On the other hand, other mint species have been shown to be rich in saponins; for example, M. spicata [34], propanol extracts of M piperita [35], water extract of M. arvensis, M. piperita [29], methanolic and chloroform extract of M. piperita, [36] ethano-water extract of M. spicata, methanol extract of M. arvensis [37].

\subsubsection{Flavonoids}

Flavonoids were present in all the plants regardless of the extract used for extraction. Flavonoids are polyphenolic compounds that constitute a large group of secondary metabolites in plants [38]. They could be useful in a pest management strategy because both flavonoids and isoflavonoids protect the plant against insect pests by influencing their behavior, growth and development [39]. Mentha plants are rich in flavonoids particularly flavones and flavanones [41]. For example, the presence of flavonoids has been reported in M. spicata [34], Mentha longifolia [42, 33], wild mint species [43-44], Mentha piperita [33, 45-46], M. spicata [47] and Mentha arvensis [37]. R. officinalis has been shown to contain flavonoids [33, 48-51]. Flavonoid insecticidal effects have 
been reported for Aedes aegypti, Drosophila melanogaster and Manduca sexta [52], Heliothis zea and Trichoplusia ni [53-54], Planococcus citri [55] and S. frugiperda [56]. Methanolic extract of M. spicatha had flavonoid content of $7.9036 \mathrm{mg} / \mathrm{mL}$ while that of R. officinalis was $6.0073 \pm 0.6117 \mathrm{mg} / \mathrm{mL}$.

\subsubsection{Glycosides}

Glycosides were present in all the plants extracts except in the methanolic extract of R. officinalis and DCM-extract of M spicata. Glycosides are compounds that result from binding of a special type of organic matter resulting from metabolism with one or more simple sugars [57]. The presence of glycosides have been reported in mint species like in M. spicata [34], M. longifolia subsp. longifolia [57]. The same has also been reported in R. officinalis by [57-62].

Insecticidal effects of glycosides have been reported by several researchers [63-69].

\subsubsection{Alkaloids}

All the solvents used were effective in extracting alkaloids of $\mathrm{M}$ spicatha and R officinalis. Presence of alkaloids in mint species such as M. spicata [34], M. longifolia [33], M. arvensis [37], M. piperita [29, 36]. R. officinalis has also been shown to contain alkaloids [33, 70]. Alkaloids are the same important group of natural substances playing an important role in insecticidal activity [71-72]. Researchers have reported this activity [68, 73-75].

\subsubsection{Tannins}

Tannins were present in all the plant extracts except the DCM- M spicata extract. Tannins are a group of water-soluble polyphenols of intermediate to high molecular weight [76]. They have been shown to be present in mint species such as M. spicata ([34], M. piperita [77-78]. They are also present in R. officinalis $[33,48,62,79-81]$.

Table 2: Charaterization of phytochemical composition of M. spicata and R. officinalis

\begin{tabular}{|c|l|c|c|c|c|c|}
\hline & SOLVENTS & Saponins & Flavonoids & Glycosides & Alkaloids & Tannins \\
\hline Plant & & & & & & \\
\hline M spicatha & DCM & - & + & - & + & + \\
\hline & Methanol & - & + & + & + & - \\
\hline & Distilled water & - & + & + & + & + \\
\hline R officinalis & DCM & + & + & + & + & + \\
\hline & Methanol & + & + & - & + & + \\
\hline & Distilled water & + & + & + & + & + \\
\hline & & & & & & + \\
\hline
\end{tabular}

Notes: + present; - Absent

\subsection{Effects of M. spicatha and R. officinalis botanical extracts on FAW larvae}

M. spicata and R. officinalis botanical extracts caused 100\% mortality to 3rd instar larvae of FAW 48 hours of exposure to the treatments as was the case for the positive control (Coragen 200 SC). These findings indicate that that the studied plant species are more effective than the species reported by [8283] in Ethiopia and Malawi, respectively.

Table 3: Effects of M spicatha and R officinalis botanical extracts on FAW larvae

\begin{tabular}{|l|l|c|c|}
\hline & TIME & 24 HOURS & 48 HOURS \\
\hline Plant & & & + \\
\hline & DCM & + & + \\
\hline R officatha & Methanol & - & + \\
\hline & Distilled water & - & + \\
\hline & DCM & - & + \\
\hline & Methanol & - & + \\
\hline & Distilled water & + & - \\
\hline
\end{tabular}

Notes: +Effective against FAW larvae (No live larvae present); - Not effective against FAW larvae (Live larvae present);

\subsection{Conclusion}

Based on the findings, it can be concluded that methanol and distilled water can be used to prepare the crude extracts of R. officinalis and M. spicata, respectively. Saponins, glycosides, alkaloid, flavonoids and tannins were present in both plant extracts. M. spicata and R. officinalis botanical extracts caused $100 \%$ mortality to 3rd instar larvae of FAW within 48 hours of exposure. Based on the findings, both M. spicata and R. officinalis have several secondary metabolites that confer insecticidal activity of the plants against FAW, hence should be evaluated under field conditions.

\subsection{Acknowledgement}

We wish to thank the Mr Lineus and Mr Odhiambo of the School of Science and Technology of the University of Kabianga for assisting with the phytochemical screening.

\subsection{References}

[1] W.C. Galinat, B.Y. Lin, “Baby corn: Production in Taiwan and future outlook for production in the United States”, Economic Botany, Vol. 42, Pp. 132-134, 1998.

[2] A. Kawatra, S. Sehgal, "Value added products of maize”, Report of the national conference on doubling maize production. New Delhi. Pp. 76-85, 2007. 
[3] Government of Kenya (GoK). Agriculture, Livestock and Fisheries Authorities (AFFA). Horticulture Validated Report; GoK: Nairobi, Kenya, 2014.

[4] R.S. Kotch, J.H. Murphy, M.D. Orzolek, P.A. Ferreti, “Factors affecting the production of baby corn”, J. Veg. Crop Prod., Vol. 1, No. 1, Pp. 19-28, 1995.

[5] J.L. Capinera, Handbook of vegetable pests. Academic Press, San Diego, 2001.

[6] F.F. Sanchez, "The economics of corn borer control in the Philippines", Proc. 7th Inter-Asian corn improvement workshop, Univiversity of the Philippines, Los Banos, Philippines, Pp. 252, 1971.

[7] G. Gorgen, P.L. Kumar, S.B. Sankung, A. Togola, and M. Tamo, "First report of outbreaks of the fall armyworm (Spodoptera frugiperda (J.E. Smith) (Lepidoptera, Nuctuidae), A new alien invasive pest in West and Central Africa", Plos One, Vol. 11, No. 10, 2016.

[8] A. Casmuz, M.L. Juarez, M.G. Socias, M.G. Murua, S. Prieto, S. Medina, E. Willink, and G. Gastaminza, "Revision de los hosped eros del gusano cogollero del maiz, Spodoptera frugiperda (Lepidoptera: Nuctuidae)", Revista de la Sociedad Entomologica Argentina, Vol. 69, No. 3-4, Pp. 209-231, 2010.

[9] R. Day, P. Abrahams, M. Bateman, T. Beale, V. Clottey, M. Cock, Y. Colmenarez, N. Corniani, R. Early, J. Godwin, J. Gomez, P.G. Moreno, S.T. Murphy, B. Oppong-Mensah, N. Phiri, C. Pratt, and S. Silvestri, "Fall armyworm: impacts and implications for Africa", Outlook Pest Man., Vol. 28, No. 5, Pp. 196-201, 2017.

[10] H. Ikeura, F. Kobayashi, and Y. Hayata, "Optimum extraction method fro volatile attractant compounds in cabbage to Pieris rapae”, Biochem Syst Ecol., Vol. 40, Pp. 201-2007, 2012.

[11] M.A. Ansari, P. Vasudevan, M. Tandon, and R.K. Razdan, "Larvicidal and mosquito repellent action of peppermint (Mentha piperita) oil”, Bioresource Technology, Vol. 71, Pp. 267-271, 2000.

[12] S. Kumar, N. Wahab, R. Warikoo, "Bioefficiency of Mentha piperita essential oil against dengue fever mosquito Aedes aegypti L", Asian Pac J Trop Biomed., Vol. 1, No. 2, Pp. 85-88, 2011.

[13] B. Binias, J. Gospodarek, M. Rusin, "Effect of water extract from mint on selected crop pests feeding and survival", Journal of Ecological engineering, Vol. 18, No. 2, Pp. 119-128, 2017.

[14] M.I. Laborda, M. Gamon, I. Gavidia, P. Perez-Bermudez, R. Boluda, "Effects of Rosmarinus officinalis and Salvia officinalis essential oil on Tetranychus urticae Koch (Acari: Tetranychidae)", Industrial Crops and Products, Vol. 48, Pp. 106-110, 2013.

[15] W. Choi, S. Lee, H. Park, Y. Ahn, "Toxicity of plant essential oils to Tetranychus urticae (Acari:Tetranychidae) and Phytoseiulus persimilis (Acari:Phytoseiidae)", Journal of Economic Entomology, Vol. 97, No. 2, Pp. 553-558, 2004.

[16] D.M. Papachristos, K.I. Karamanoli, D.C. Stamopoulos, U. Menkissoglu-Spiroudi, "The relationship between the chemical composition of three essential oils and their insecticidal activity against Acanthoscelides obtectus (Say)", Pest management Science, vol. 6, No. 5, Pp. 514-520, 2004.

[17] I. Tunc, B.M. Berger, F. Erler, F. Dagli, "Ovicidal activity of essential oils from plants against two stored-product insects”, J. Stored Prod. Res., Vol. 36, Pp. 161-168, 2000 .

[18] E.A. Koschier, K.A. Sedy, “Labiate essential oils affecting host plant selection and acceptance of Thrips tabaci Lindeman," Crop Pro., Vol. 22, Pp. 929939, 2003.

[19] M.B. Isman, J.A. Wilson, R. Bradbury, "Insecticidal activities of commercial rosemary oils (Rosmarinus officinalis) against larvae of Pseudaletia unipuncta and Trichoplusia ni in relation to their chemical compositions", Journal of Pharmaceutical Biology, Vol. 46, No. 1-2, Pp. 82-87, 2008

[20] G.M. Panazai, M. Javaid, S. Shahid, W. Noor, Z. Bibi, A. Ejaz, "Effect of four plant extracts against Trigoderma granarium and Tribolium casteneum", Pak J. Bot., Vol. 51, No. 3, Pp. 1149-1153.

[21] A.M. Al-Jabr, "Toxicity and repellency of seven plant essential oils to Oryzaephilus surinamensis (Coleoptera:Silvanidae) and Tribolium castaneum (Coleoptera: Tenebrioidae)", Scientific Journal of King Faisal University (Basic and Applied Sciences), Vol. 7, No. 1, Pp. 49-60, 2006.

[22] P.W. Deryck, “Laboratory rearing of the Fall armyworm”, Florida Entomological Society, Vol. 62, No. 2, Pp. 87-91, 1979.

[23] I. Cruz, M. Lourdes, D. Silva, E. Foster, "Efficiency of chemical pesticides to control Spodoptera frugiperda and validation of pheromone traps as a pest management tool in the maize crop", Revista Brasileira de Milho e Sorgo, Vol. 9, No. 2, Pp. 107-122, 2010.

[24] J.T. Hardke, B.R. Leonard, F. Huang, R.E. Jackson, "Damage and survivorship of fall armyworm (Lepidoptera: Noctuidae) on transgenic field corn expressing Bacillus thuringiensis Cry Proteins”, Journal of Crop Protection, Vol. 30, Pp. 168-172, 2011.

[25] A. Sofowora, "Medicinal plants and traditional medicine in Africa", Spectrum Books Ltd. Ibadan, Nigeria, Pp. 191-289, 1993.

[26] G.E. Trease, W.C. Evans, “Pharmacognosy”, 11th edn. Bailliere Tindall, London, Pp. 45-50, 1989.

[27] J.B. Harboene, “Phytochemical methods”, Chapman and Hall Ltd. London, Pp. 49-188, 1973.

[28] R.S. Odhiambo, P.G. Kareri, E.K. Mwangi, D.W. Onyango, “Contraceptive and phytochemical profile of lime-yellow pea (Macrotyloma axillare, E. Mey)”, Verdc: A tropical climber. European J. Med. Plants., Vol. 19, No. 2, Pp. 1-13, 2017.

[29] M.M. Mainasara, B.L. Aliero, A.A. Aliero, M. Yakubu, "Phytochemical and antibacterial properties of root and leaf extracts of Calotropis procera", Nigerian Journal of Basic and Applied Science, Vol. 20, No. 1, Pp. 1-6, 2012.

[30] J.R. De Oliveira, S.E.A. Camargo, L.D. de Oliveira, "Rosemarinus officinalis L (Rosemary) as therapeutic and prophylactic agent", Journal of Biomedical Science, Vol. 26, No. 5, Pp. 1-22, 2019.

[31] D. Gioia, S.A. Petropoulos, "Phytoestrogens, phytosteroids and saponins in vegetables: Biosynthesis, functions, health effects and practical applications", Adv Food Nutr Res., Vol. 90, Pp. 351-421, 2019. 
[32] D. Asha, L. Mathew, R.S. Iyer, P.S. Sayana, L.V. Bose, "Isolation and characterization of novel saponin from Rosmarinus officinalis L. (Lamiaceae)", International Journal of advanced Research, Vol. 5, No. 2, Pp. 1743-1749, 2017.

[33] I.M. Khamis, A.A. Aly, "Preliminary phytochemical screening of different solvent extracts of some medicinal plants", Middle East Journal of applied Sciences, Vol. 7, No. 2, Pp. 226-231, 2017.

[34] A. Soni, S. Sosa, "Phytochemical analysis and free radical scavenging potential of herbal and medicinal plant extracts", Journal of Pharmacognosy and phytochemistry, Vol. 2, No. 4, Pp. 22-29, 2013.

[35] P. Kumar, S. Mishra, A. Malik, S. Satya, "Development of emulsified concentrate (EC) formulation of Mentha piperita oil for control of mosquito larvae", Malar J., Vol. 11, No. 1, Pp. 58, 2012.

[36] K.Y. Wenji, I. Rukmi, A. Suprihadi, "Invitro antifungal activity of methanolic and chloroform mint leaves (Mentha piperita L.) extracts against Candida albicans", J. Phys. Conf. Ser., 1217012136, 2019.

[37] A. Sharma, S. Patel, "Preliminary phytochemical analysis and antbacterial activity of Mentha arvensis L. against Xanthomonas citri", Internationa Journal of Applied Research, Vol. 3, No. 6, Pp. 382-386, 2017.

[38] R. Erenler, B. Meral, O. Sen, M., Elmastas, A. Aydin, O. Eminagaoglu, G. Topcu, "Bioassay-guided isolation, identification of compounds from Origanum rotundifolium and investigation of their antiproliferative and antioxidant activities”, Journal of Pharmaceutical Biology, Vol. 55, No. 1, Pp. 1646-1653, 2017.

[39] M.S. Simmonds, "Flavonoid-insect interactions: Recent advances in our knowledge", Phytochemistry, Vol. 64, Pp. 21-30, 2003.

[40] M.S. Simmonds, P.C. Stevenson, "Effects of isoflavonoids from cicer on larvae of Helicoverpa armigera", Journal of Chemical Ecology, Vol. 27, Pp. 965977, 2001.

[41] K. Kapp, "Polyphenolic and essential oil composition of Mentha and their antimicrobial effect", Faculty of Phamacy of the University of Helinki, Pp. 1$73,2015$.

[42] D.M. Stanisavljevic, S.S. Stojlcevic, S.M. Dordevic, B.P. Zlatkovic, D.T. Velickovic, I.T. Karabegovic, M.L. Lazic, "Antioxidant activity, the content of total phenols and flavonoids in the ethanol extracts of Mentha longifolia (L.) Hudson dried by the use of different techniques", Chemical Industry and Chemical Engineering Quarterly, Vol. 18, No. 3, Pp. 411-420, 2012.

[43] A. Benabdallah, C. Rahmoune, M. Boumendjel, O. Aissi, C. Messaoud, "Total phenolic content and antioxidant activity of six wild Mentha species (Lamiaceae) from northeast of Algeria", Asian Pacific Journal of Tropical Biomedicine, Vol. 6, No. 9, Pp. 760-766, 2016.

[44] A.A. Gaafar, M.U. Nooman, A.I. Eman, M.M. Ali, A.S. Al-kashef, "Prophylactic and therapeutic uses of Egyptian Mentha spicata, L. Mentha piperita L. and Ocimum basilicum L. stalks as Agro-industrial byproducts”, Journal of Biological Sciences, Vol. 18, No. 7, Pp. 354-363, 2018.

[45] Z. Sroka, I. Fecka, C. Wojciech, “Antiradical and anti-H2O2 properties of polyphenolic compounds from an aqueous peppermint extract”, Z Naturforsch, Vol. 60, Pp. 826-832, 2005

[46] D.L. McKay, J.B. Blumberg, “A review of the bioactivity and potential health benefits of peppermint tea (Mentha piperita L.)”, Phytother Res., Vol. 20, No. 8, Pp. 619-633, 2006

[47] R. Naidu, R. Ismail, C. Yeng, S. Sasidharan, P. Kumar, "Chemical composition and antioxidant activity of the crude methanolic extracts of Mentha spicata”, Phytology, Vol. 4, No. 1, Pp. 13-18, 2012.

[48] N. Okamura, H. Haraguchi, K. Hashimoto, A. Yagi, “Flavonoids in Rosmarinus officinalis leaves”, Phytochemistry, Vol. 37 , No. 5, Pp. 1463-1466, 1994.

[49] P. Mena, M. Cirlini, M. Tassotti, K.A. Herrlinger, C.Dall Asta, D. DelRio, "Phytochemical profiling of flavonoids, phenolic acids, terpenoids and volatile fraction of Rosemary (Rosmarinus officinalis L.) extract”, Molecules, Vol. 21, Pp. 1576-1590, 2016.

[50] N. Bai, K. He, M. Roller, C.S. Lai, X. Shao, M.H. Pan, C.T. Ho, "Flavonoids and phenolic compounds from Rosmarinus officinalis," Journal of Agricultural and Food Chemistry, Vol. 58, Pp. 5363-5367, 2010.

[51] B.F. Zimmermann, S.G. Walch, L.N. Tinzoh, W. Stuhlinger, D.W. Lachenmeier, "Rapid UHPLC determination of polyphenols in aqueous infusions of Salvia officinalis L. (Sage tea)”, Journal of Chromatography B. Analytical Technologies in the Biomedical and Life Sciences, Vol. 879, Pp. 2459-2464, 2011.

[52] M.J. Mitchell, D.P. Keogh, J.R. Crooks, S.L. Smith, "Effects of flavonoids and other allelochemicals on insect cytochrome P-450 dependant steroid hydroxylase activity", Insect Biochemistry and molecular Biology, Vol. 23, Pp. 65-71, 1993.

[53] C.B. Hoffmann-Campo, "Role of the flavonoids in the natural resistance of soybean to Helioths virescens (F>) and Trichoplusia ni (Hubner)", Dissertation (Ph.D). The University of Reading, Reading, Pp. 165, 1995.

[54] C.B. Hoffmann-Campo, J.B. Harborne, A.R. McCaffery, "Pre-ingestive and post-ingestive effects of soya bean extracts and rutin on Trichoplusia ni growth", Entomologia Experimentalis et Applicata, Vol. 98, Pp. 181-194, 2001.

[55] N. Nukmal, E.A. Rosa, M. Kanedi, "Insecticidal effects of the flavonoid-rich fraction of leaves extract of Gamal (Gliricidia sepium) on the Cofee mealybugs (Planococcus citri Risso.)”, Annual Research \& Review in Biology, Vol. 16, No. 6, Pp. 1-9, 2017.

[56] G.N. Diaz Napal, S.M. Palacios, "Bioinsecticidal effects of the flavonoid’s pinocembrin and quercetin against Spodoptera frugiperda”, J. Pest. Sci., Vol. 88, Pp. 629-635, 2015.

[57] D.H. Abdul-Hakeem, H.J. Alhadithi, S.T. Hadi, "Estimation of total phenolic compounds, essential oils and antibacterial activity of tannins and glycosides extracted from Rosemary (Rosmarinus officinalis L.) and wild mint (Mentha longifolia L.)”, Advances in Environmental Biology, Vol. 13, No. 5, Pp. 14$18,2019$.

[58] N. Mimica-Dukic, V. Jacovljevic, M. Popovic, O. Gasic, A. Szabo, "Pharmacological study of Mentha longifolia phenolic extracts", Int. J. Pharmacogn., Vol. 34, Pp. 359-364, 1996. 
[59] K. Sasaki, A. El Omri, S. Kondo, J. Han, H. Isoda, "Rosemarinus officinalis polyphenols produce anti-depresant like effect through monoaminergic and cholinergic functions modulation", Behav. Brain Res., Vol. 238, Pp. 86-94, 2013.

[60] M. Muchuweti, E. Kativu, C.H. Mupure, C. Chidewe, A.R. Ndhlala, M.A.N. Benhura, "Phenolic composition and antioxidant properties of some spices", American Journal of Food Technology, Vol. 2, No. 5, Pp. 414-420, 2007.

[61] Z. Nadia, M. Rachid, “Antioxidant and antibacterial activities of Thymus vulgaris L”, Med. Aromat. Plant Res. J., Vol. 1, No. 1, Pp. 5-11, 2013.

[62] P.N. Lumb, "Investigation of the in vitro antimicrobial activity of Rosmarinus officinalis (Rosemary) essential oil against micro-organisms in burn wound infections", Dissertation (BSc.). The University of Nairobi. Nairobi, Pp. 45, 2015.

[63] S. Nobsathian, T. Ruttanaphan, V. Bullangpoti, "Insecticidal effects of Triterpene glycosides extracted from Holothuria atra (Echinoderma:Holothuroidea) against Spodoptera litura (Lepidoptera:Noctuidae)", J. Econ Entomol., Vol. 112, No. 4, Pp. 1683-1687, 2019.

[64] A.A. Alzabib, Y. Abobakr, A.S. Al-Sarar, H.I. Hussein, O.A. Basudan, A.A. El-Gamal, M.S. Abdel-Kader, H.M. El-Komy, "Molluscicidal activity of cardiac glycosides isolated from Adenium obesum", Pest Management Science, Vol. 75, No. 10, Pp. 2770-2775, 2019.

[65] D.H. Al-Rajhy, A.M. Alahmed, H.I. Hussein, S.M. Kheir, "Acaricidal effects of cardiac glycosides, azadirachtin and neem oil against the camel tick, Hyalomma dromedarii (Acari:Ixodidae)”, Pest Management Science, Vol. 59, Pp. 1250-1254, 2003.

[66] D.S. Park, J.R. Coats, “Cyanogenic glycosides: Alternative insecticides”, The Korean Journal of Pesticides Science, Vol. 6, No. 2, Pp. 51-57, 2006.

[67] H. Dave, L. Lediwane, "A review on anthraquinones isolated from Cassia species and their applications", Indian Journal of Natural Products and Resources, Vol. 3, Pp. 291-319, 2012.

[68] K. Velu, D. Elumalai, P. Hemalatha, M. Babu, A. Janaki, P.K. Kaleena, "Phytochemical screening and larvicidal activity of peel extracts of Arachis hypogea against chikungunya and malarial vectors", International Journal of mosquito Research, Vol. 2, No. 1, Pp. 1-8, 2015.

[69] Z. Wimmer, J.F.D.M. Alexandra, M. Floro, Zarevucka, M. Wimmerova, G. Sello, F. Orsini, "Insect pest control agents: Novel chiral butanoate esters (juvenogens)", Bioorganic and Medicinal chemistry, Vol. 15, No. 18, Pp. 6037-6042, 2007.

[70] S.M. Edrah, Fouzy, Alafid, I. Ales, A. Kaled, A.I. Soad, H. Radim, "Phytochemical screening and antibacterial activity of Genista microcephala and Rosemarinus officinalis extracts from Libyan’s regions", Int. J. Res. Ayurveda Pharm., Vol. 8, No. 4 Pp. 1-5, 2017.

[71] M.F. Balandrin, J.A. Klocke, E.S. Wurtele, W.H. Bollinger, "Natural plant chemicals: Sources of industrial and medicinal materials", Science, Vol. 7, No. 28, Pp. 1154-1160, 1985.

[72] R.S. Rattan, “Mechanisms of action of insecticidal secondary metabolites of plant origin”, Crop protection, Vol. 29, Pp. 913-920, 2010.

[73] S.W. Wachira, S. Omar, J.W. Jacob, M. Wahome, H.T. Alborn, D.R. Spring, B. Torto, “Toxicity of six plant extracts and two pyridine alkaloids from Ricinus communis against the malaria vector Anopheles gambiae", Parasites \& Vectors, Vol. 7, Pp. 312, 2014.

[74] A.M. Emam, E.S. Swelam, N.Y. Megally, "Furocoumarin and quinolone alkaloid with larvicidal and antifeedant activities isolated fron Ruta chalepensis leaves", Journal of Natural products, Vol. 2, Pp. 10-22, 2009.

[75] F. Acheuk, B. Doumandji-Mitiche, "Insecticidal activity of alkaloids extract of Pergularia tomentosa (Asclepiadaceae) against fifth instar larvae of Locusta migratoria cinerascens (Fabricius 1781) Orthoptera:Acrididae)", International Journal of Science and Advanced Technology, Vol. 3, No. 6, Pp. 8-13, 2013.

[76] R.A. Alkurd, H.R. Takruri, H. Al-Sayyed, “Tannin contents of selected plants used in Jordan”, Journal of Agricultural Sciences, Vol. 4, No. 3, Pp. 265-274, 2008.

[77] D.M. Pramila, R. Xavier, K. Marimuthu, S. Kathiresan, M.L. Khoo, M. Senthilkumar, K. Sathya, S. Sreeramanan, "Phytochemical analysis and antimicrobial potential of methanolic leaf extract of peppermint (Mentha piperita: Lamiaceae)”, J. Med. Plants Res., Vol. 6, No. 2, Pp. 331-335, 2012.

[78] V.L. Christova-Bagdassarian, K.S. Bagolassarian, M.S. Atanassova, M.A. Ahmad, "Comparative analysis of total phenolic and total flavonoid contents, Rutin, Tannins and antioxidant capapcity in Apiaceae and Lamiaceae families", Indian Horticulture Journal, Vol. 4, No. 3/4, Pp. 131-140, 2014.

[79] D. Sasikumar, M. Selvam, N.K.A. Al-Shammari, "Evaluating the pharmacological dose (Oral LD50) and antibacterial activity of leaf extracts of Mentha piperita Linn Grown in Kingdom of Saudi Arabia: A pilot study for Nephrotoxicity", International Journal of Pharmacology, Vol. 12, Pp. 195-200, 2016.

[80] M. Cuvelier, C. Berset, H. Richard, “Antioxidant constituents in sage (Salvia officinalis)”, J. Agric. Food Chem., Vol. 42, Pp. 665-669, 1994.

[81] Y. Lu, Y. Foo, “Antioxidant activities of polyphenols from sage (Salvia officinalis)”, Food Chem., Vol. 72, Pp. 197-202, 2001.

[82] B. Sisay, T. Tefera, M. Wakgari, G. Ayalew, E. Mendesil, "The efficacy of selected synthetic insecticides and botanicals against Fall armyworm, Spodoptera frugiperda in maize”, Insects, Vol. 10, Pp. 45-58, 2019.

[83] K. Phambala, Y. Tembo, T. Kasambala, V.H. Kabambe, P.C Stevenson, S.R. Belmain, "Bioactivity of common pesticidal plants on fall armyworm larvae (Spodoptera frugiperda)", Plants, Vol. 9, 2020. 